Motivação dos Atos Administrativos

Por Cláudia Travi Pitta Pinheiro

Data da defesa da dissertação: 20/11/2007

Orientador: Almiro do Couto e Silva

A dissertaçăo investiga os contornos do dever de motivação dos atos administrativos no sistema jurídico brasileiro. O estudo inicia pela análise de seus fundamentos constitucionais, surgimento e desenvolvimento, destacando as diferenças e semelhanças com sua origem e evolução em outros sistemas jurídicos. A perspectiva comparativa está presente tamběm nos capítulos subseqüentes, em que se definem o conteúdo da norma, seu âmbito de aplicação e as conseqüências do descumprimento do dever. O olhar crítico sobre a jurisprudência das cortes brasileiras permeia todos os capítulos do trabalho.

A Banca Examinadora foi composta pelos Professores Doutores: Humberto Bergmann Ávila, Professor da Universidade Federal do Rio Grande do Sul e Doutor em Direito pela Universidade de Munique, LMU, Alemanha; Itiberê de Oliveira Rodrigues, Professor da Universidade Federal de Pelotas e Doutor em Direito pela Universitat Munster (Westfalische-Wilhelms), W.W.U.M., Alemanha; Regina Linden Ruaro, Professora da Pontificia Universidade Católica do Rio Grande do Sul e Doutora em Direito pela Universidad Complutense de Madrid, U.C.M., Espanha. A referida defesa foi presidida pelo Professor Almiro do Couto e Silva.

\title{
A Funcionalidade do Ônus da Prova no Processo Civil Brasileiro
}

Por Juliana Leite Ribeiro do Vale

Data da defesa da dissertação: 29/11/2007

Orientador: Carlos Alberto Alvaro de Oliveira

Diante de uma situação de insuficiência probatória, o juiz, impossibilitado de pronunciar o non liquet, deve julgar segundo a regra do ônus da prova. No entanto, em algumas situações, a aplicação da regra prevista no artigo 333 do Código de Processo Civil pode culminar em injustiças. Para evitá-la, a doutrina, a jurisprudência e a legislação apresentam criativas soluçóes. Na tentativa de sistematizá-las, o trabalho analisa, sob a óptica do juiz, da lei e das partes, alguns fenômenos relacionados ao ônus da prova no Processo Civil brasileiro.

A banca examinadora foi composta pelos Professores Doutores: Danilo Knijnik, Professor da Universidade do Vale do Rio dos Sinos e 